\title{
MULTILATERAL DEVELOPMENT BANKS AND STATE CAPACITY: THE IDB, BRAZIL AND ARGENTINA IN THE NEOLIBERAL ERA
} (1990-2002)

\section{BANCOS DE DESENVOLVIMENTO MULTILATERAL E CAPACIDADE ESTATAL: O IDB, BRASIL E ARGENTINA NA ERA NEOLIBERAL}

Rogério Makino ${ }^{1}$

\begin{abstract}
The article analyzes the relation between the Inter-American Development Bank's Modernization of the State programs and the state capacity of Brazil and Argentina during the Neoliberal Era in Latin America (1990-2002). The development studies indicate that state capacity is a precondition for any successful development strategy. Thus, a greater state capacity could be expected from those countries who participated in these programs, but the data obtained does not permit this conclusion.
\end{abstract}

Keywords: multilateral development; banks; state capacity.

Resumo: O artigo analisa a relação entre os Programas de Modernização do Estado do Banco Interamericano de Desenvolvimento e a capacidade estatal do Brasil e da Argentina durante a Era Neoliberal na América Latina (1990-2002). Os estudos sobre desenvolvimento indicam que a capacidade do Estado é uma condição prévia para qualquer estratégia de desenvolvimento bem-sucedida. Assim, uma maior capacidade Estatal poderia ser esperada dos países que participaram desses programas, mas os dados obtidos não permitem essa conclusão.

Palavras-chave: desenvolvimento multilateral; bancos; capacidade estatal.

\section{INTRODUCTION}

In the studies about State and development for the last three decades, especially in the Institutionalist Perspective, state capacity has been increasingly considered as a necessary but insufficient condition for development. Development banks target "development" as a goal, but this concept does not have only one meaning and it is not static or accepted by everyone. Thus, both state capacity and development banks are in the same realm - the development process. This article focuses on the relation between multilateral development banks and the enhancement of state capacity. It is assumed that the effectiveness of development strategies cannot be separated from the state capacity of countries (LANGE \& RUESCHMEYER, 2005).

\footnotetext{
${ }^{1}$ Mestre em Relações Internacionais e Doutor em Ciências Sociais. Professor junto à Universidade do Estado do Mato Grosso. E-mail: makinotga@gmail.com.
} 
In empirical terms, the selected cases were the relations between the IDB - the InterAmerican Development Bank - and Brazil and between the IDB and Argentina. This bank is the oldest and the largest multilateral development bank of the world and these two countries are its two most important borrowers. The analyzed period is from 1990 to 2002, when the neoliberal ideas started to attract many adepts in Latin America and when the IDB found a favorable environment to propose the restructuring of the State through a new category of programs: Reform/Modernization of the State. Theoretically, this is the category with the greatest potential to enhance state capacity.

The research design was comparative, focusing on the IDB-Brazil and the IDBArgentina relations and their impact on the state capacity of those countries. The operationalization of the concept of state capacity was inspired in the parameters described by Hendrix (2010): the tax collection capacity and the quality of the bureaucratic administrative staff. The information sources were Brazil's and Argentina's Loan Proposals and Project Completion Reports of the IDB's Modernization of State programs, available on the IDB's website.

The article is organized in three sections and the conclusions. The first addresses the theoretical context of the concept of state capacity. The second presents the IDB's summarized history and description. The third analyzes the impact of the Modernization of State programs on Brazil's and Argentina's state capacity.

\section{INSTITUTIONALISMS AND STATE CAPACITY}

The guiding concept of this research - state capacity - started to have its heuristic potential explored as the discussion about institutions came back in late eighties and in the early nineties. According to Acuña (2013), the concept of institution followed a winding path in Social Sciences so that the association between institutions, enforced State and development only became consolidated as Institutionalism started to be discussed again, especially New Institutionalism. For one of those new institutionalists:

\footnotetext{
"Institutions are the foundation of social life. They consist of formal and informal rules, monitoring and enforcement mechanisms, and systems of meaning that define the context within which individuals, corporations, labor unions, nation-states, and other organizations operate and interact with each other. Institutions are settlements born from struggle and bargaining. They reflect the resources and power of those who made them and, in turn, affect the distribution of resources of power in society. Once created, institutions are powerful external forces that help determine how people make sense of
} 
their world and act in it. They channel and regulate conflict and thus ensure stability in society." (CAMPBELL, 2004, p. 01)

In other words, as organizers of social life, institutions are present in every aspect of human action: cultural, political, and economic or in their intersection. However, the explanation about the nature of institutions and its implications varies. Schmidt (2008) distinguishes four types of Institutionalisms: rational-choice, historical, sociological, and discursive. The first one emphasizes the potential of institutions to reduce transaction costs and uncertainties. The second one focuses on the path dependence in the process of building institutions. The third one embraces the idea that institutions are embedded in cultural norms. The fourth one considers all the aspects mentioned above, but it is especially concerned with the dynamic character of the production of ideas and discourses around the institutions in their different levels of generality. In this last type, it is assumed that institutions are maintained by the production and reproduction of ideas so that discursive analyses can be a key tool to investigate them.

One of the institutionalist contributions to the Political Economy is the critique of the institutional monoculture, that is, the naturalization of the idea that some institutions are superior and should be adopted by all the countries. Another contribution is the skepticism about an inevitable opposition between State and market as antagonistic forces, and the diagnosis of a bad economic performance due to excessive state intervention. For many new institutionalists, the real point is how different institutional settlements can contribute to the reproduction of capital. In other words, some of them had serious doubts about the neoliberal ideas, which were rising in the 1990's.

The discussion about state capacity became notorious when the theories which tried to explain politics and government action shifted from the society-centered perspectives (e. g. Pluralism and Structural Functionalism) to those interested in the State itself. The former presented the State as an arena where interests and preferences from different groups of society were disputed, while the latter tended to understand the State as a great institution or a set of interwoven institutions. It is important to note that in studies about development, previous hegemonic theories (e. g. Theory of Modernization and Theory of Dependence) were weakening (Kjaer \& Hansen, 2002).

As most of the concepts in Social Sciences, state capacity does not have a unanimous accepted definition. Among recent Brazilian institutionalist studies, Gomide \& Pires (2014: 
19-20) present state capacity as embedded in the institutional set - "set of rules, mechanisms and processes which define the particular form that actors and interests are coordinated in the implementation of specific policies". Amongst other contemporary perspectives on the subject, one of the most famous definition is credited to Skocpol, who assumes the weberian "monopoly of the legitimate use of violence within a given territory", but emphasizes the autonomy of the State and its capacity to set and persecute goals.

\begin{abstract}
"States conceived as organizations claiming control over territories and people may formulate and pursue goals that are not simply reflective of the demands or interests of social groups, classes or society. This is what is usually meant by "state autonomy". Unless such independent goal formulation occurs, there is little need to talk about states as important actors. Pursuing matters further, one may then explore the 'capacities' of states to implement official goals, especially over the actual or potential opposition of powerful social groups or in the face of recalcitrant socioeconomic circumstances." (Skocpol, 1985, p. 09)
\end{abstract}

In recent research, Saylor (2013) tries to identify the common features marked by the most famous conceptualizations of state capacity: control over territory; major coercive power; tax collection capacity; penetration of society via military or institutional alliances; regulation of social relationships; and direction of (some) economic production.

Table 1 - Conceptualization of State Capacity

\begin{tabular}{|l|c|c|c|c|c|c|c|c|}
\hline & $\begin{array}{l}\text { Barnett } \\
(1992: 41- \\
\text { 49) }\end{array}$ & $\begin{array}{l}\text { Grindle } \\
(1996: \\
3-8)\end{array}$ & $\begin{array}{l}\text { Huber } \\
(1995)\end{array}$ & $\begin{array}{l}\text { Mann } \\
(1984)\end{array}$ & $\begin{array}{l}\text { Migdal } \\
(1988: \\
4-5)\end{array}$ & $\begin{array}{l}\text { Skocpol } \\
(1985 \\
16-17)\end{array}$ & $\begin{array}{l}\text { Slater } \\
(2010: \\
3-4)\end{array}$ & $\begin{array}{c}\text { Smith } \\
(2007: \\
52-55)\end{array}$ \\
\hline $\begin{array}{l}\text { Controls } \\
\text { territory }\end{array}$ & $\mathbf{X}$ & $\mathbf{X}$ & $\mathbf{X}$ & $\mathbf{X}$ & & $\mathbf{X}$ & $\mathbf{X}$ & $\mathbf{X}$ \\
\hline $\begin{array}{l}\text { Possesses } \\
\text { preponderant } \\
\text { coercive } \\
\text { forces }\end{array}$ & $\mathbf{X}$ & $\mathbf{X}$ & $\mathbf{X}$ & $\mathbf{X}$ & $\mathbf{X}$ & $\mathbf{X}$ & $\mathbf{X}$ & $\mathbf{X}$ \\
\hline $\begin{array}{l}\text { Extracts } \\
\text { revenue }\end{array}$ & $\mathbf{X}$ & $\mathbf{X}$ & $\mathbf{X}$ & $\mathbf{X}$ & $\mathbf{X}$ & $\mathbf{X}$ & $\mathbf{X}$ & $\mathbf{X}$ \\
\hline $\begin{array}{l}\text { Penetrates } \\
\text { society via } \\
\text { alliances, } \\
\text { military or } \\
\text { institutions }\end{array}$ & $\mathbf{X}$ & $\mathbf{X}$ & $\mathbf{X}$ & $\mathbf{X}$ & $\mathbf{X}$ & & $\mathbf{X}$ & $\mathbf{X}$ \\
\hline $\begin{array}{l}\text { Regulates } \\
\text { social } \\
\text { relationships }\end{array}$ & $\mathbf{X}$ & & & & & $\mathbf{X}$ & & \\
\hline $\begin{array}{l}\text { Directs } \\
\text { some) } \\
\text { economic } \\
\text { production }\end{array}$ & & & & & & & & \\
\hline
\end{tabular}


Source: Saylor (2013: 15)

For development studies, Skocpol's conceptualization has some advantages such as emphasis on elaboration and persecution of goals - especially policies and strategies - and the idea of a relatively autonomous State - the opposite idea of a State captured by the specific interests of a group or social class over the rest of society. It is interesting to note that these two features mentioned above are also very common in the studies of the developmental state. According to the author, some prerequisites of state capacity are sovereignty, stable administrative and military control, loyal and qualified civil servants (weberian bureaucracy) and sufficient material and financial resources.

Among the most important works about historical state-building are Charles Tilly's The Formation of National States in Western Europe and Coercion, Capital and European States. According to the author, the need for resources for war demanded the building of a tax collection system such that the state became structured around it. In other words, since there was permanent foreign threat to the recent and fragile sovereignties, the costs of defense could only be paid for a functional tax collection system. Meanwhile, an efficient bureaucracy would also be necessary to manage these resources.

The political organization of the Nation-state was a non-intentional and unplanned consequence of the rising of this state capacity or, in other words, an "externality of the extractive practice" of contingent nature. Three elementary features can be observed in this infant polity: extractive capacity (tax collection capacity), military power, and administrative organization. According to Tilly, this form of political organization was born in Western Europe and spread worldwide later.

Hendrix (2010) points out that most of studies operationalize state capacity highlighting two features: tax collection capacity and quality of the bureaucratic administrative staff. The author defends that these two features are also the two main preconditions of state capacity so that its enhancement demands the improvement of these features. The data analysis, in this research, was guided by that idea.

\section{MULTILATERAL DEVELOPMENT BANKS AND IDB}

A development bank is defined by the fact that its loans, programs and fundings are targeted to development-oriented projects. Its conception can be traced back to the World War II, when the development theories were rising. According to Leys \& Shaw (1996: 7), these theories were associated with the concerns of European powers to accelerate the economic 
growth of their colonies because of the perspective of a soon decolonization. By that moment, economic growth and development were taken as synonymous and the State was considered to have an important role to channel foreign capital and induce growth. In this context, development banks could be important partners to these States. Besides, theses banks could help in countercyclical policies, keeping liquidity in periods of crisis, when private banks tend to shorten the supply of credit (FERRAZ et al, 2013). Multilateral development banks are like credit cooperatives where their borrowers are also owners of the bank (COUTO, 1999: 4647). Additionally, it must be mentioned that regional development banks are multilateral development banks which are defined by geographical criteria.

The IDB's mandate and structure served as a model for international organizations alike which were later created such as the African Development Bank, the Asian Development Bank and the Caribbean Development Bank (BARRIA \& ROPER, 2004: 620). Historically it has been Latin America's largest multilateral source of funding. It aims to assist development projects in the region with more favorable conditions than those from the private market. As other banks of this nature, the IDB is a declared non-profit organization, although financial sustainability is essential to its survival as a financial institution.

Its members can be classified into two groups: the borrowers and the non-borrowers. Among the first group are the countries that can obtain loans and take advantage of the IDB's programs. They must necessarily be from Latin America or Caribbean. The second group includes the countries that cannot obtain loans. They can be from the region (the United States or Canada) or from somewhere else (many countries from Europe, Japan, China and Israel, for instance). Currently, the IDB has 48 members: 26 borrowers and 22 non-borrowers. The Bank is organized as in an anonymous society, i.e., the members have voting rights proportional to their shares in the Bank.

Table 2 - Voting Power of Selected Countries in 2009 (percentage)

\begin{tabular}{|c|c|c|c|}
\hline $\begin{array}{l}\text { Geographic } \\
\text { Localization }\end{array}$ & Status & Country & Voting Power \\
\hline \multirow[t]{9}{*}{ Regional } & \multirow{7}{*}{$\begin{array}{l}\text { Borrower } \\
(\mathbf{5 0 , 0 1 5 \% )}\end{array}$} & Brazil & $10,751 \%$ \\
\hline & & Argentina & $10,751 \%$ \\
\hline & & Mexico & $6,912 \%$ \\
\hline & & Venezuela & $5,761 \%$ \\
\hline & & Chile & $2,953 \%$ \\
\hline & & Colombia & $2,953 \%$ \\
\hline & & Others & $9,935 \%$ \\
\hline & \multirow{2}{*}{$\begin{array}{l}\text { Non-Borrower } \\
(\mathbf{3 4 , 0 0 7 \% )}\end{array}$} & United States & $30,006 \%$ \\
\hline & & Canada & $4,001 \%$ \\
\hline Not Regional & Non-Borrower & Japan & $5,001 \%$ \\
\hline
\end{tabular}




\begin{tabular}{|l|l|l|l|}
\hline \multirow{3}{*}{$(\mathbf{1 5 , 9 7 8 \% )}$} & France & $\mathbf{1 , 8 9 6 \%}$ \\
\cline { 2 - 3 } & Germany & $\mathbf{1 , 8 9 6 \%}$ \\
\cline { 2 - 3 } & Italia & $\mathbf{1 , 8 9 6 \%}$ \\
\cline { 2 - 3 } & Spain & $\mathbf{1 , 8 9 6 \%}$ \\
\cline { 2 - 3 } & Other & $\mathbf{3 , 3 8 8 \%}$ \\
\hline
\end{tabular}

Source: IDB. Voting Power. Accessed in 31/10/2017 Available in: http://idbdocs.iadb.org/wsdocs/getdocument.aspx?docnum=35104877

The administrative structure of the Bank, similar to that of the World Bank, is composed of the Board of Governors, Board of Executive Directors and the Presidency. The first one is the IDB's most important administrative office, where the governors - who represent the countries - vote according to their share in the Bank. It usually delegates power to the Board of Executive Directors, who actually manages the ordinary and daily operations, especially loans, guarantees, country strategies, administrative budget, interest rate, etc. The fourteen directors are elected or nominated by the Board of Governors for a term of three years. The United States and Canada have one specific director to represent each one of them and the other twelve directors represent the other countries (some of them represent more than one country). The president of the IDB, elected by the Board of Governors for a term of five years (s/he can be re-elected once), legally represents the institution, conducts the everyday business and leads the meetings of the Executive Board. The president votes only in cases of ties. The presidency always belongs to a Latin American and the vice presidency to an American (COUTO, 1999).

The resources of the Bank are classified as Ordinary Capital and Fund for Special Operations. The former is the available capital for most of the Bank's operations; it comes from the compulsory quota paid for each one of the members, resources from the capital market and from the payment of conceived loans. The latter targets the poorest countries in the region and its resources come from the donations of the IDB's members.

Barria \& Roper (2004) explain that the context and the conditions at the foundation of a development bank influence its membership, its mandate, its structure and the lending policy. In the case of the IDB, some authors comment that many of the original features have persisted throughout the years, as its emphasis on technical cooperation and low-interest lending policy. Couto (1999: 46) defends that the IDB is closer to an ideal type of multilateral development bank targeting a specific geographic region than any other organization. Largely, it's justified by a unique settlement where most of the resources would come from the United States, while the borrowers would hold the majority of the voting power. Besides, some 
concerns at the time of the Bank was founded were institutionalized as different requirements according to the borrower's capacity or development level, and the connection among cooperation, technical assistance and funding.

At that time, some factors such as the Keynesian influence about the State role in the economy, the legitimacy of the expansion of welfare policies in the United States during Roosevelt's government, and the philosophy of Marshall Plan favored the foundation of a development bank. Meanwhile, the rising of development theories and the structuralistindustrialist approach from the United Nations Economic Commission for Latin American and the Caribbean (ECLA) offered ideas which influenced the region and the role of the development banks. In addition, the Cold War order and the fear that Communism could present itself as an interesting alternative to the countries in the region created favorable political conditions to the foundation of a development bank, since it could not be possible without the participation of the United States.

The IDB was created in 1959, when the United States finally agreed to participate and provide the resources for the Bank. Couto (1999) points out that the Brazilian president Juscelino Kubitschek had already insisted with the American government that underdevelopment could push Latin America into the communist direction. But the United States only took it seriously by the time of the Cuban Revolution in 1958. In other words, the immediate cause of the creation of the IDB is related to security considerations and the constraints of Cold War.

Since the beginning, some features were often discussed by many authors: tolerance and a better comprehension of the region's problems, empathy with Latin American development due to the nature of the Bank, more favorable rules for the vulnerable countries in the region, the approval of loans or projects according to the financial and technical viability and evaluation of merits. According to Couto (1999: 40), "the Bank is its members' server, not their master".

Although these more favorable conditions offered by the Bank to the countries in the region are often emphasized in many places, other important issues cannot be underestimated. As any other institution (especially an international financial institution), the continuation of its existence is conditioned by available resources and the interests coming from some people and groups. In order to survive in the banking world, development banks should offer more favorable conditions, but they could not risk their own financial balance either. 
The emphasis on Latin America's effective role in the Bank management and foundation is a kind of self-propaganda, presented in many of the Bank's publications, e.g., annual reports, project completion reports, booklets, books, internet page, seminars organized by the institution, etc. The propaganda and real favorable conditions definitely made it a viable option for its members. However, the Latin America's real influence on the Bank has been less than the IDB's discourse emphasizes.

Focusing excessively on the Latin American identity may eclipse the real American influence on the Bank. Some episodes illustrate the sometimes underestimated influence of the United States: Cuba's exclusion from the IDB and the suspension of loans to Nicaragua during the Sandinista Revolution and to Panama under Noriega's government in the late eighties. They were part of the American foreign policy to leftist movements in Latin America and Caribbean. Actually, never has a loan been made if the United States opposed to it (TUSSIE, 1995, p. 31).

From the beginning of the IDB's activities in the sixties to the late eighties, there was a strong complementarity between the Bank's original development mandate and the consensus around the development strategies that the countries from the region should follow. According to Tussie (1995: 21; 79-80), this mandate targeted the funding of investment projects and the provision of technical cooperation to the most vulnerable countries in the region. Throughout the Bank's history, there was a pendulum swinging between the necessities of balancing, on one side, the funding of viable projects and, on the other, reducing poverty or saving the environment.

Majorly influenced by ECLA's ideas, the structuralist and dependentista prognosis, widespread in Latin America, was the urgent need for regional industrialization to overcome underdevelopment, the dependent condition and the declining terms of trade. However, the industrialization in these countries would face many challenges such as the precarious infrastructure. This kind of project usually needs high investments and takes a long time to return feedback, especially in places where the capital market is barely developed and risk averse. At this time, it was a common belief that since there was lack of private actors willing to take risks in projects of this nature, the State should do it. For most of Latin American countries, the necessary volume of resources for such investments was far beyond their capacities. Besides, other types of investment such as sanitation were not commonly financed by private banks, such that when IDB started to support these projects, it was nicknamed 
"water and sanitation bank". Its first project was the water treatment and sanitation in Arequipa in Peru in 1961. According to Tussie (1995: 03; 49), the IDB was responsible for two thirds of the investments in drinking water during the sixties and seventies in Latin America. Even when the World Bank started to finance this kind of projects in the eighties, the IDB didn't lose the leadership in this market. Likewise the IDB was also known as "university bank", because of its programs in education, and "integration bank", because of its programs of regional integration.

In the sixties, the IDB's funding was based on the submission and examination of projects. The productive sector (agriculture, industry and mining) represented $40 \%$ of the projects, the infrastructure (transportation, communication and energy) 30\%, the social investment (water and sanitation, housing and education) $25 \%$ and the others $5 \%$. In the seventies, the Bank stimulated the creation of institutions that could implement the projects and provide services associated with them. In the eighties, the Bank had considered the possibility of reserving $50 \%$ of its resource for low income groups, but the Latin American Debt Crisis compelled the IDB to channel part of the available resources to help countries with problems in their balances of payment (VÍVARES, 2013, p. 58).

Late eighties and early nineties represented a turning point to IDB and its relations with its borrowers. In the ideological sphere, the developmentalism paradigm highly influenced by ECLA's structuralist ideas, which had conditioned the creation of the Bank and its activities for three decades, was being considered a failed utopia. Meanwhile, some countries, e.g. the United States and the United Kingdom, watched the rising of friendly governments to neoliberal ideas. Actually, since the Fourth Replenishment in 1976, the United States showed little enthusiasm with the Bank, and its stance was eminent in the following decade.

During one of the most severe crisis for Latin American countries in the $20^{\text {th }}$ century, the Debt Crisis, the IDB's resources were not sufficient to assist all of its borrowers and they could not honor their debts with the Bank either. According to Vivares (2013), the United States demonstrated that they would not contribute any form of replenishment if major changes were not introduced: greater voting power to the Americans and the IDB's submission to the World Bank's guidelines, which were convergent with the Washington Consensus and its neoliberal ideas. In other words, either the IDB supported IMF's prescriptions for structural adjustment or the United States would let the regional 
development bank become resourceless. Araújo (1991) believes that by this moment the IDB was close to the end of its activities, because it was believed that Latin America would not agree with the American's requirements.

Rist (2008: 171; 178) notices a discursive shift in the development agencies in that time: the concept of "development" built in the Post World War II, associated with the idea of national project, center-periphery, world-system, declining terms of trade and import substitution industrialization, was losing space to a new vocabulary in which "structural adjust" was the central notion, softened by "humanitarian extras" (some resource to fight extreme poverty) and new issues, e.g., environmentalism (sustainable development) and globalization. It means that this "new development" had to do with economic growth driven by global integration and free flow of financial capital and products with compensatory measures to relief poverty. Since these agencies needed to survive, but could not justify their existence by the old utopia, they had to invent another one.

The Seventh Replenishment was approved in March 1989 and the United States managed to impose some changes. The first was that the United States, Canada and any third country could agree together to postpone the approval of projects or loans. The second one was that sectorial (or policy-based) loans ${ }^{2}$ would be co-financed by the IDB and the World Bank for two years, renewable for two more years. Actually, it meant that the borrower was cornered by exigencies of the two institutions, i.e., even if the country could avoid or block the IDB's conditionalities, it could not do the same with the World Bank's (ARAÚJO, 1991: 54). Between the years 1989 and 2002, there were more than seventy co-financed loans to Latin America. Argentina and Mexico made the largest number of these kinds of loans; they received the greatest volume of resources from co-financed loans. Brazil was the third country who received the greatest volume of resources because of a single loan taken during the devaluation of the country's currency in $1999^{3}$.

During the nineties, the neoliberal ideas had strongly influenced the IDB's programs and guidelines. Jonakin (2001) believes that a new form of market fundamentalism took over the Bank, since it kept insisting on programs with repeated experiences of failure. The reform policies looked to be decided in advance, while the theoretical conviction would come later to adjust the necessary justifications.

\footnotetext{
${ }^{2}$ Sectorial Loans and Policy-Based Loans (abbreviation: PBLs) are synonimous. They had "conditionatilities" imposition-like exigences made by some international financial organizations which sometimes had high political and economic cost for the borrower.

${ }^{3}$ This was also the only loan with conditionality that Brazil made during the period from 1989 to 2002 .
} 
This context meant some changes in the relation between the IDB and its borrowers, but it's important to mention that some of the features persisted: the IDB continued to be Latin America's most important multilateral source of funding for development projects and Brazil, Argentina and Mexico continued to be the major borrowers in volume of resources.

Among the new features were: 1) Infrastructure and Productive Sector, the most important program categories in the previous decades, continued to exist, but some others were created or had their importance increased such as Environment and Modernization of State. The latter incorporated the principles of this "new development" and became the Bank's major priority in the Eighth Replenishment in 1995, since the IDB and other financial institutions believed that part of the Latin American underdevelopment was due to a model of State which urged to be reformed and modernized; 2) The Social programs also continued to exist, but from this moment on they started to have a compensatory nature associated with negative side effects of the Structural Reforms; 3) The convergence between the IDB, the World Bank and IMF about the policies that should be adopted by the countries in the subcontinent become notorious in that decade ${ }^{4}$; 4) The programs with subnational units as States or Provinces and Municipalities increased; 5) The IDB started to defend that democratic processes should be deepened in the region, although its own practices were often accused by many critics of little deliberation and transparency.

\section{THE IDB'S MODERNIZATION OF STATE PROGRAMS: A COMPARISON OF THE BRAZILIAN AND THE ARGENTINIAN CASES}

Even though the IDB has funded many infrastructure and social programs, the most interesting category for this study is the Modernization of State, since its programs are those with greater potential to impact state capacity. In this category, the ideal State defended by international financial organization - especially the IDB, the World Bank and IMF - can be clearly observed. They remarked that Latin American States had an excessively large scope of activities, interfered deliberately in the economic realm generating distortions and inefficiency, exercised outdated principles of Public Administration, and lacked democracy.

The Modernization of State covered a large range of programs which included the defense of democratic practices, the decentralization of policy-making processes, the reform of Public Administration targeting more efficiency, and even the support to the privatization

\footnotetext{
${ }^{4}$ Vianna Jr (2000) and Acuña \& Tuozzo (2000) identifies submission from the IDB and the World Bank to the IMF during this
} 
of State companies. Those programs were received with varying degrees of enthusiasm and suspicion, reflecting Latin America's heterogeneity. Some countries, remarkably Argentina, signed many of these programs, while others signed only a few. Brazil, for instance, was the sixth most important borrower in the Modernization of State programs between 1990 e 2002, although it was Latin America's largest economy.

During the period mentioned above, Brazil signed 39 Modernization of State programs - representing $14 \%$ of all programs signed and $6 \%$ of the resources received from the Bank. It is important to note that 29 of these programs were technical cooperation, which usually cost less and have more limited impact than ordinary loans. Brazil made only one Policy-Based Loan. It was not classified as Modernization of State program, but as a Social Sector Loan. Among the co-financed programs by the IDB and the World Bank, there was none in the category of Modernization of State.

Table 3 - Brazil's Modernization of State Programs between 1990 and 2002 (technical cooperation not included)

\begin{tabular}{|l|l|}
\hline $\begin{array}{l}\text { Number of the Project and } \\
\text { Year of Approval }\end{array}$ & Name of the Project \\
\hline BR0166/1994 & Strengthening of Ministry of Foreign Affairs \\
\hline BR0193/1995 & $\begin{array}{l}\text { TC Loan Tax Administration (Brazilian Federal Revenue } \\
\text { Office) }\end{array}$ \\
\hline BR0171/1996 & $\begin{array}{l}\text { National Fiscal Administration Program for Brazilian } \\
\text { States }\end{array}$ \\
\hline BR0175/1997 & TC Loan Ipea Network, IBGE, FGV, and Other \\
\hline BR0220/1997 & the Federal Government Modernization Program \\
\hline BR0256/1998 & Municipal Development of Porto Alegre \\
\hline BR0288/1998 & Parliamentary Power Integration \\
\hline BR0286/1999 & Fiscal Management of Brazilian Municipalities \\
\hline BR0327/2001 & the Pension System Management Modernization \\
\hline BR0365/2002 & $\begin{array}{l}\text { Modernization Comptroller Office (TCU- Tribunal de } \\
\text { Contas da União) }\end{array}$ \\
\hline
\end{tabular}

Source: Elaborated by the author

Taking into account the theoretical and methodological parameters of state capacity defended by Hendrix (2010), the ten ordinary loans of that category were analyzed. Broadly speaking, the improvement of the administrative bureaucratic staff and the incentives to the officials were not important issues in the Modernization of State programs. Sometimes, courses and specific training were included, but generally secondary to the introduction of new equipment and technology. There were two exceptions, where these issues were 
explicitly mentioned: the Pension System Management Modernization (BR-0327) and the Federal Government Modernization Program (BR-0220). In the latter, there was only a preliminary study about the possibility of reorganizing the civil service, which did not actually happen.

Five out of ten programs included measures to increase the tax collection capacity: TC Loan Tax Administration (BR-0193), National Fiscal Administration Program for Brazilian States (BR-0171), Municipal Development of Porto Alegre (BR-0256), Fiscal Management of Brazilian Municipalities (BR-0286), and the Modernization of Pension System Management (BR-0327). However, it was a priority only in the first three programs mentioned above. The IDB's diagnosis was that the biggest problem in tax collection was bureaucratism, slowness and inefficient organization. In order to overcome these problems would be necessary to use new equipment and technology (especially computers) and to update the rules, the organization, and the management strategies. Since these measures were elaborated from a very limited diagnosis, its potential to improve tax collection capacity was also limited and only incremental gains could take place.

There was an increase in the tax collection and in the tax burden in the late 1990s and early 2000s, but the absolute majority of experts in the subject do not credit it to the improvement of the tax collection capacity or the decrease of tax evasion. They credit the increase of existing tax rates and the creation of new taxes, especially the federal consumption taxes (taxes on goods and services), which did not have to be shared with States and Municipalities and were easier to collect, e.g., COFINS, PIS, CPMF and CIDE-Combustíveis. None of the IDB's programs targeted specifically the improvement of consumption tax collection; one of the most important in this subject targeted the income tax.

There was an increase of resources collected by the income tax under the responsibility of the Receita Federal (Brazilian Federal Revenue Office), which was “modernized" by one of the IDB's program in the Fernando Henrique Cardoso's government. However, none of the consulted authors (SALVADOR, 2006; BRAMI-CELENTANO \&CARVALHO, 2007; GIAMBIAGI, 2008) credits this increase to the modernization of the Receita Federal; they all believe that the non-updating (freezing) of the income tax table throughout the years forced many previously exempt individuals to become taxpayers.

In the Argentinian case, between 1990 and 2002, there were 43 Modernization of State programs - 25 loans and 18 technical cooperation. The programs of this category represented 
$20 \%$ of the projects and $55 \%$ of the resources received from the IDB during this time. Argentina was the country which benefited the most in Modernization of State programs. It had the largest number of Modernization of State policy-based loans and general policy-based loans. Among the ten co-financed loans by the IDB and the World Bank, six were Modernization of State programs. In sum, this category was very important to Argentina, which feared no deep commitment with this kind of programs and their ideals.

Table 4 - Argentina's Modernization of State Programs between 1994 and 2002 (pure technical cooperation not included)

\begin{tabular}{|l|l|}
\hline $\begin{array}{l}\text { Number of the } \\
\text { Project and Year of } \\
\text { Approval }\end{array}$ & Name of the Project \\
\hline AR0149/1994 & Administration Financing Reform Public Sector \\
\hline AR0187/1995 & Provincial Bank Privatization \\
\hline AR0201/1996 & Provincial Pension System \\
\hline AR0164/1996 & Province Support Program for Buenos Aires \\
\hline AR0144/1997 & Support for Enterprise Restructuring \\
\hline AR0220/1997 & Institutionalized Support AFIP \\
\hline AR0218/1998 & Fiscal Reform Support for Grand City of Buenos Aires \\
\hline AR0254/1998 & $\begin{array}{l}\text { Special Structural Adjustment Program and Strengthening of } \\
\text { Banking System Safeguards }\end{array}$ \\
\hline AR0260/1998 & $\underline{\text { Repo: Security Banking S. From AR0254 }}$ \\
\hline AR0256/1999 & $\underline{\text { Strengthening Foreign Trade Policy }}$ \\
\hline AR0265/2000 & $\underline{\text { Institutional Strengthening of the Ministry of Foreign Relations, }}$ \\
\hline AR0257/2000 & Staternational Trade and Worship \\
\hline AR0271/2000 & $\underline{\text { Fiscal Balance \& Social Management Program }}$ \\
\hline AR0266/2001 & Financial Sector Program \\
\hline AR0283/2001 & $\underline{\text { PEF:AR0266 Financial Sector Program }}$ \\
\hline AR0284/2001 & $\underline{\text { Support Financial Services Sector }}$ \\
\hline AR0280/2001 & Fiscal Support Sectoral Program \\
\hline S0urce: E196010
\end{tabular}

Source: Elaborated by the author

From the analyzed programs ${ }^{5}$, three of them considered the improvement of the quality of the bureaucratic administrative staff through training and courses, organizational restructuring or career and salary plans: Institutionalized Support AFIP ${ }^{6}$ (AR0220), Fiscal Reform Support for Grand City of Buenos Aires (AR0218), and State Modernization of

\footnotetext{
${ }^{5}$ It was not possible to analyze the 25 Modernization of State Programs, since many of the Loan Proposals and Project Completion Reports were not available online in the IDB's website in the time of this research was taking place. Only documents post-1994 were available.

${ }^{6}$ AFIP or Administración Federal de Ingresos Públicos is one of the country's most important tax collection institutions.
} 
Cordoba Province (AR0257). In the AR0220 and AR0218, the results of the programs were not considered by the Bank's completion reports as completely satisfactory. In other words, the quality of the bureaucratic administrative staff was not a priority in the Modernization of States programs for Argentina and when they were considered, the results were not surprisingly positive.

Six programs included the increasing of tax collection capacity: Provincial Pension System AR0201, Province Support Program for Buenos Aires AR0164, Institutionalized Support AFIP AR0220, Reform Support for Grand City of Buenos Aires AR0218, State Modernization of Cordoba Province AR0257, and Fiscal Support Sectoral Program AR0280. In most cases, reports considered that the results were satisfactory, although the Argentinian Crisis and the end of the Convertibility Plan had complicated an accurate evaluation. As those programs were elaborated on the basis of the same limited principles applied to the Brazilian case, the results were not very different from incremental ones in most of them. But there were two important exceptions: the AFIP and Pension System programs.

The AFIP program targeted broader and deeper reforms, not only the traditional modernization of equipment (informatization) and the introduction of new management techniques. It included, for instance, the revision of rules and suggestions of changes in the legislation, simplification of bureaucratic procedures, expansion of control, and organizational restructuring of this agency. Although a simple and automatic association between the IDB's program and the enhancement of the AFIP is not possible, there was a notorious increase of the tax collected while the program was taking place. Between 1997 and 2004, AFIP doubled the volume of resources collected. ${ }^{7}$

On the other hand, the Pension System Program, trying to substitute the old model of pension by a new one where the private sector would have a more important role, had counter-productive effects, generating a huge and chronic deficit. Vivares (2013) believes that this problem in the pension system was an important factor to understand the breakdown of the Argentinian Convertibility (1 peso exchangeable for 1 dollar).

The IDB's Modernization of State programs were much more important to Argentina than to Brazil; this is evident in the comparison of the number of projects, volume of resources in this category, co-financed programs, and policy-based loans. These differences probably are related to the distinct paths of Brazil's and Argentina's political economies and,

\footnotetext{
${ }^{7}$ According to the Project Completion Report of the AR0220.
} 
consequently, to their distinct levels of enthusiasm with the neoliberal principles that conditioned these programs. The developmentalism ideals which guided policy-makers in Brazil for almost six uninterrupted decades (1930-1989) could not simply disappear overnight. The generations socialized under this paradigm would have a tendency to show resistance to the neoliberal ideas. On the other hand, Argentina had a shorter and less intense developmentalist experience.

Table 5 - The Modernization of State Programs in Brazil and Argentina (1990-2002)

\begin{tabular}{|l|l|l|l|}
\hline \multicolumn{2}{|l|}{$\begin{array}{l}\text { Brazil } \\
\begin{array}{l}\text { State Programs } \\
\text { (number of } \\
\text { approved projects) }\end{array}\end{array}$} & $\begin{array}{l}39 \\
(29 \text { were technical } \\
\text { cooperation) }\end{array}$ & $\begin{array}{l}43 \\
(18 \text { were technical } \\
\text { cooperation) }\end{array}$ \\
\cline { 2 - 4 } & $\begin{array}{l}\text { Proportional to all } \\
\text { approved projects }\end{array}$ & $14 \%$ & $20 \%$ \\
\hline $\begin{array}{l}\text { Modernization of } \\
\text { State Programs } \\
\text { (volume of } \\
\text { resources) }\end{array}$ & $\begin{array}{l}\text { Proportional to all } \\
\text { approved projects }\end{array}$ & $6 \%$ & 9 \\
\hline $\begin{array}{l}\text { IDB's Policy-Based Loans of the } \\
\text { Modernization of State }\end{array}$ & 0 & 6 \\
\hline $\begin{array}{l}\text { Co-financed Loans of Modernization of } \\
\text { State }\end{array}$ & 0 & \\
\hline
\end{tabular}

Source: Elaborated by the author

In the regard of the improvement of the bureaucratic administrative staff, the effects in both countries were not expected to initiate a revolution, since it was not a real priority, according to the main goals set in the proposals of the Modernization of State programs. Similarly, the objectives about the improvement of tax collection capacity were not ambitious, based mostly in the technological modernization (new computers and softwares) and the introduction of new administrative procedures. They did not really target one of the most important limiting factors in tax collection in Latin America: tax evasion in its multiple dimensions. ${ }^{8}$ According to the IDB Project Completion Reports, most of the results were discreet. The two exceptions, which happened to Argentina, point to opposite directions: one to the increase of tax collection and the other to the decrease of it. Argentina's deeper

\footnotetext{
${ }^{8}$ The mainstream studies about tax evasion are based on rational-choice models, in which individuals analyze costs and benefits of their actions. If the probability of punishment is low, the incentive to evade is high, as in countries where institutions are weak. Allington and Sandmo (1972) are some of the pioneers in this perspective. Others researchers focus on the low legimity of the government (Linhares, 2011) or the lack of a civicrepublican culture (Bresser-Pereira, 1997).
} 
commitment with the Bank's ideals and programs solely resulted in neither only the improvement nor only the deterioration of the tax collect capacity; sometimes they had only incremental gains as it happened to less committed countries, but in other cases there was intensification, making good results better and bad ones worse.

\section{FINAL CONSIDERATIONS}

The comparison between the Brazilian case, less convergent with the Bank's new notion of development, and the Argentinian case, ideologically closer to the IDB's programs, does not allow us to conclude that there is an automatic positive or negative relation between the Modernization of State programs and the enhancement of state capacity during the studied period. However, it suggests an ambiguous potential to magnify both good and bad results.

All development banks present "development" as their major goal, but the promotion of the features required for the increase of state capacity was not in the Bank's agenda during the Neoliberal period. This absence may have happened because countries with greater state capacity (what requires qualified and loyal civil servants to national interests) value their autonomy, explore their freedom of action and prefer to be "on the driver's seat". If all the countries were endowed with great state capacity, they could take care of their projects and development strategies autonomously, doing without these development bank's programs. The ultimate consequences of this scenario would be an intense pressure for these banks to reinvent themselves completely or to cease existing. In the neoliberal resignification of development, there was no room for the notions such as autonomy and national interests. Perhaps, that is why that period was unfavorable to anything associated with state capacity.

\section{REFERENCES}

ACUÑA, Carlos H. (org.) ¿Cuánto importán las insituciones? Gobierno, Estado y actors en la política argentina. Buenos Aires, Siglo Veintuno Editores, 2013.

ACUÑA, Carlos. H., \& TUOZZO, María Fernanda. Civil Society Participation in World Bank and Inter-American Development Bank Programs: The Case of Argentina. Global Governance, 2000, p. 433-456.

ALLINGHAM, Michael G.; SANDMO, Agnar. Income Tax Evasion: a theoretical analysis. Journal of Public Economics n ${ }^{\circ}$ 1, 1972, p. 323-338.

ARAÚJO, Aloísio Barboza. O Governo Brasileiro, o BIRD e o BID: cooperação e confronto. Instituto de Pesquisa Econômica Aplicada (IPEA), v. 131. Brasília, 1991.

BARRIA, Lilia A.; ROPER, Steve D. Economic Transition in Latin America and PostCommunist Countries: a comparison of multilateral development Banks. International Journal of Politics, Culture and Society. Volume 17, Issue 4, June, 2004, p. 619-638. 
BRAMI-CELENTANO, Alexandrine; CARVALHO, Carlos Eduardo. A reforma tributária do governo Lula: continuísmo e injustiça fiscal. Revista Katálysis, v. 10, n. 1, 2007, p. 44-53.

BRESSER-PEREIRA, Luiz Carlos. Cidadania e res publica: a emergência dos direitos republicanos. Revista de Filosofia Política, v. 1, 1997, p. 99-144.

CAMPBELL, John L. Institutional Change and Globalization. Princeton University Press, 2004.

COUTO, Ronaldo Costa. A História Viva do BID e o Brasil. Banco Interamericano de Desenvolvimento, 1999.

FERRAZ, João Carlos; ALÉM, Ana Cláudia Duarte de; MADEIRA, Rodrigo Ferreira. A contribuição dos bancos de desenvolvimento para o financiamento de longo prazo. Revista do BNDES, Rio de Janeiro, n. 40, 2013, p. 5-42.

GIAMBIAGI, Fabio. 18 anos de política fiscal no Brasil: 1991/2008. Economia aplicada, v. 12, n. 4, 2008, p. 535-580.

GOMIDE, Alexandre de Ávila; PIRES, Roberto Rocha C. Capacidades estatais e democracia: arranjos institucionais de políticas públicas. Brasília: IPEA, 2014.

HENDRIX, Cullen S. Measuring State Capacity: theoretical and empirical implications for the study of civil conflict. Journal of Peace Research, v. 47, n. 3, 2010, p. 273-285.

INTER-AMERICAN DEVELOPMENT BANK. Annual Reports. (Editions from 1990 to 2002)

from 1990 to 2002). Loan Proposals (Modernization of State Programs

Programs).

Project Completion Reports (Modernization of State

JONAKIN, Jon. The Inter-American Development Bank's Assessment of Structural Adjustment: Questionable Theory and Pre-Ordained Policy.Canadian Journal of Latin American and Caribbean Studies, v. 26, n. 51, 2001, p. 49-81.

KJÆR, Mette; HANSEN, Ole H.; THOMSEN, Jens PF. Conceptualizing state capacity. Democracy, the State, and Administrative Reforms Research Report, nº6, 2002.

LANGE, Matthew; RUESCHEMEYER, Dietrich (Ed.). States and development: historical antecedents of stagnation and advance. Palgrave Macmillan, 2005.

LEYS, Colin; SHAW, D. J. The Rise \& Fall of Development Theory. EAEP, 1996.

LINHARES, Bianca de Freitas. Cultura Política e Percepção Tributária: uma análise sobre a sustentação da democracia brasileira. Tese (Doutorado em Ciência Política). Porto Alegre: UFRG, 2001.

RIST, Gilbert. The History of Development: from western origins to global faith. 3rd edition. Zed Books, 2008.

SALVADOR, Evilásio. A distribuição da carga tributária: quem paga a conta. Arrecadação, p. 7992, 2006.

SAYLOR, Ryan. State Building in Boom Times: Commodities and Coalitions in Latin America and Africa. Oxford University Press, 2014.

SKOCPOL, Theda; EVANS, Peter B.; RUESCHEMEYER, Dietrich (Ed.) .Bringing the state back in. Cambridge University Press, 1985.

SCHMIDT, Vivien A. Discursive institutionalism: The explanatory power of ideas and discourse. Annu. Rev. Polit. Sci., v. 11, 2008, p. 303-326. 
TILLY, Charles. The Formation of National States in Western Europe. Princeton, NJ: Princeton University Press, 1975.

1984.

. Big structures, large processes, huge comparisons. Russell Sage Foundation,

TUSSIE, Diana. The Inter-American Development Bank. Multilateral Development Banks, volume 4. Lynne Rienner Publishers Inc, 1975.

VIANNA JR, Aurélio. Civil Society Participation in World Bank and Inter-American Development Bank Programs: The Case of Brazil. Global Governance, 2000, 457-472.

VIVARES, Ernesto. Financing Regional Growth and the Inter-American Development Bank: The Case of Argentina. Routledge, 2013.

Recebido em 10/10/2017.

Aceito em 23/11/2017.

Publicado em 02/04/2018. 